\title{
THE CLT PANELS IN STRUCTURAL RESTORATION: CHARACTERISTICS AND TECHNICAL REGULATIONS
}

\author{
PROF. ING. GIORGIO FRUNZIO ${ }^{1 *}$, ING. LUCIANA DI GENNARO ${ }^{2}$ ING. LUIGI \\ MASSARO $^{3}$ AND ING. FABIO D' ANGELO ${ }^{4}$ \\ ${ }^{1 *}$ Department of Architecture and Industrial Design \\ Univesità degli Studi della Campania "Luigi Vanvitelli" \\ Abbazia di San Lorenzo ad Septimum 81031 Aversa (CE), Italy \\ e-mail: giorgio.frunzio@unicampania.it -Web page: https://www.unicampania.it \\ ${ }^{2}$ Department of Engineering \\ Univesità degli Studi della Campania "Luigi Vanvitelli" \\ Via Roma 2981031 Aversa (CE), Italy \\ e-mail: luciana.digennaro@unicampania.it \\ ${ }^{3}$ Soc. M. \& P. s.a.s. di Massaro Cesare \& C. \\ Via Ovidio 2 - 81033 - Casal di Principe (CE), Italy \\ e-mail: ing.luigi.massaro@gmail.com \\ ${ }^{4}$ TECNOLAB srl
}

Via S. Maria del pianto, 80 - 80143 - Napoli, Italy

e-mail: info@tecnolabnapoli.it - Web page: http://www.tecnolabnapoli.it

Keywords: Wood, CLT panels, Masonry, Historical Structure, laboratory tests

\begin{abstract}
Wood can represent a valid and important alternative to the most commonly used structural materials for the restoration of masonry buildings, with a view to efficient, effective and "conscious" renovation. Today, the modern technologies allows to overcome the structural limits of solid wood due to its own anisotropy. The use of composite wood elements makes possible to obtain excellent mechanical performances that consent to evaluate aspects such as the use of low environmental impact retrofit strategies. The aim of this work is the analysis of mechanical parameters related to CLT (cross laminated timber) panels in order to determine their possible use in the structural restoration of masonry buildings. The CLT panels consist of solid wood planks superimposed so that each layer has the fibres rotated ninety degrees with respect to the adjacent layer. The layers (always in odd number and at least three) can be connected by discrete joints, pins and nails, or glued together. This configuration enables to product large structural elements with considerable thickness. Two different experimental test campaigns were carried out on samples of panels with three and five glued layers. The purpose of experimentation activities was to evaluate the bending deformation of the wooden elements and shear strength of the bonding sections. All the tests were processed according to the provisions contained in the UNI standards. The test results were then compared with different theoretical calculation models to determine the one that best represents the tested material. The tests outcomes have shown that some characteristics of the material, such as the remarkable ductility, open different scenarios of use for the CLT panels in the field of structural restoration of masonry buildings.
\end{abstract}




\section{INTRODUCTION}

The purpose of this work is to provide some assessments of the possibility of using structural wood-based products such as CLT panels, for the restoration of existing masonry buildings both ordinary that monumental ones. The CLT panels consist of a series of layers of solid wood lamellas placed with the fibres rotated by $90^{\circ}$ with respect to the adjacent layers, therefore by their own nature these elements are suitable for interventions to reinforce of the structures in their own plan. It is also considered that these elements can be a valid solution to the reinforcement of the structural elements for actions out of their own plan in order to increase both their resistance than their ductility, using for example prestressing techniques such as PressLam ${ }^{\circledR}[2,4]$, performing fully reversible interventions.

In this note, we intend to study the possible applications of CLT panels in the restoration of masonry buildings both in relation to the techniques used to date than in relation to other future perspectives.

These structural wood-based panels are to date widely used in the structural reinforce of the timber floors in order to increase their strength to the actions that operate in their own plan $[5,6,7,8,9,10,11,12,13]$. It is considered essential to better know the mechanical properties and laws that govern the behaviour of this material subjected to stress, in order to evaluate the possibility of extending its use to other field of application.

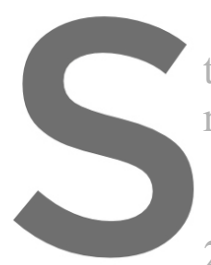

The working group

technical regulations resistance of the gluing

The results of these

2. TECHNICAL REGULATIONS

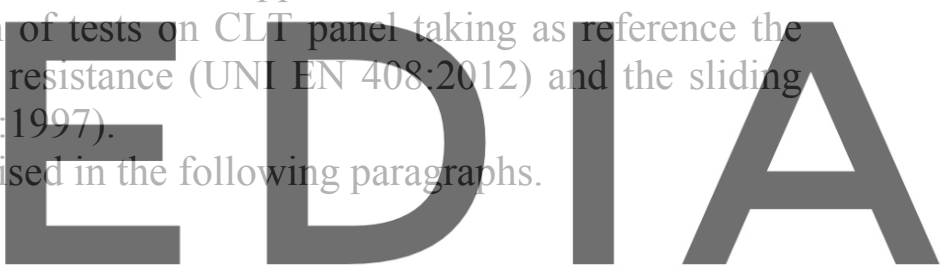

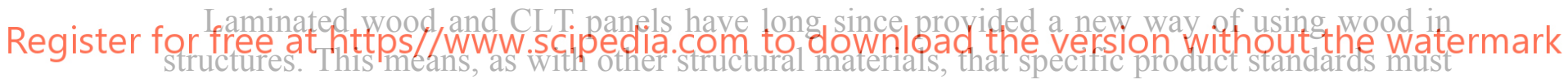
be drawn up. These standards define the types of structural material, their mechanical properties and estabilish how to determine them.

Below are the regulations in force which seem to be relevant in this case.

\subsection{Strutture}

- UNI EN 1995-1-1:2014 - Eurocodice 5 - Progettazione delle strutture di legno - Parte 1-1: Regole generali - Regole comuni e regole per gli edifici. (Design of wooden structures - Part 1-1: General regulations - Common regulations and regulations for buildings)

- ETAG 007 - GUIDELINE FOR EUROPEAN TECHNICAL APPROVAL of TIMBER BUILDING KITS

- Norme tecniche per le costruzioni (NTC 2018). D. Min. Infrastrutture e Trasporti 17 gennaio 2018 (Technical standards for construction (NTC 2018))

- CNR-DT 206/2007 Istruzioni per la Progettazione, l’Esecuzione ed il Controllo delle Strutture di Legno (Instructions for Design, Execution and Control of Wooden Structures) 
- Circolare 21 gennaio 2019 n.7 " Istruzioni per l'applicazione dell' «Aggiornamento delle "Norme tecniche per le costruzioni" » di cui al decreto ministeriale 17 gennaio 2018" (Circular January 21, 2019 n.7 "Instructions for the application of the «Update of the "Technical standards for construction"》 referred to in the Ministerial Decree of 17 January 2018)

- Direttiva del Presidente del Consiglio dei Ministri 9 febbraio 2011 Valutazione e riduzione del rischio sismico del patrimonio culturale con riferimento alle Norme tecniche per le costruzioni di cui al D.M. 14/01/2008. (Assessment and reduction of seismic risk of cultural heritage with reference to the Technical Standards for constructions referred to in D.M. 14/01/2008.)

\subsection{Materials}

- ISO 16572:2008 Timber structures -- Wood-based panels -- Test methods for structural properties

ISO 16696-1:2019 Timber structures -- Cross laminated timber Component performance, production requirements and certification scheme

UNI EN 13017-1,2 :2001 - Pannelli di legno massiccio - Classificazione in base all'aspetto delle facce - Conifere/Latifoglie; (Solid wood panels - classification according to face appearance - coniferous/hardwood)

This standard is the official Italian version of the European standard EN 13017-1

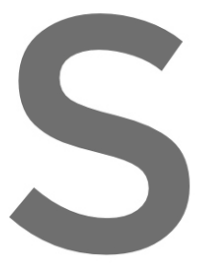

(edition Novenib

classes for both

latter having

coniferous/hardwood.

UNI EN 12775:2002 - Pannelli di legno

(Solid wood pandls - Classification and
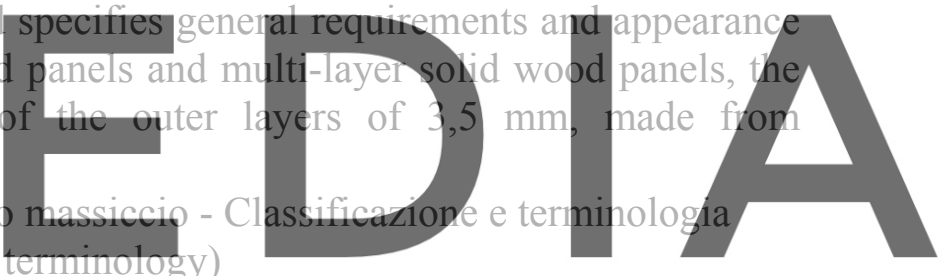

This standard is the official Italian version of the European standard EN 12775

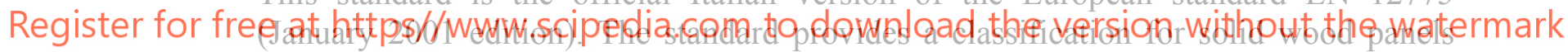

and defines the terms used.

- UNi EN 13353:2011 - Pannelli di legno massiccio (SWP) - Requisiti. (Solid wood panels (SWP) - Requirements)

This standard is the official English version of the European standard EN 13353:2008+A1 (May 2011 edition). The standard specifies the requirements for solid wood panels as defined in UNI EN 12775, with a maximum thickness of $80 \mathrm{~mm}$, for use in dry, humid and outdoor environments, as defined by service classes 1, 2 and 3 of UNI EN 1995-1-1.

- $\quad$ UNI EN 14081-3:2012 - Strutture di legno - Legno strutturale con sezione rettangolare classificato secondo la resistenza - Parte 3: Classificazione a macchina; requisiti aggiuntivi per il controllo di produzione in fabbrica. (Structural wood with rectangular cross-section classified according to strength - Part 3: Machine classification; additional requirements for factory production control)

- UNI EN 14080:2013 - Strutture di legno - Legno lamellare incollato e legno massiccio incollato - Requisiti (Wooden structures - Glued lamellar wood and glued solid wood Requirements) 
- UNI EN 14081-2:2013 - Strutture di legno - Legno strutturale con sezione rettangolare classificato secondo la resistenza - Parte 2: Classificazione a macchina - Requisiti aggiuntivi per le prove iniziali di tipo. (Wooden structures - Structural wood with rectangular cross-section classified according to strength - Part 2: Machine classification - Additional requirements for initial type tests.)

- UNI EN 14081-1:2016 - Strutture di legno - Legno strutturale con sezione rettangolare classificato secondo la resistenza - Parte 1: Requisiti generali (Wooden structures Structural wood with rectangular cross-section classified according to strength - Part 1: General requirements)

- UNI EN 338:2016 - Legno strutturale - Classi di resistenza (Structural wood Resistance classes)

- UNI EN 14358:2016 Strutture di legno - Calcolo e verifica dei valori caratteristici (Wooden structures - Calculation and verification of characteristic values)

\subsection{Laboratory Tests}

ISO 8375:2017 Timber structures -- Glued laminated timber -- Test methods for determination of physical and mechanical properties.

UNI EN 313-1:1997 - Pannelli di legno compensato. Classificazione e terminologia. Classificazione. (Plywood panels. Classification and terminology. Classification.) UNI EN 392:1997 - Legno lamellare incollato. Prova di resistenza a taglio delle

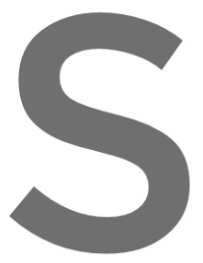
superfici di incollaggid. (Glued laminat
surfaces.)
UNI EN 314-1:2005 - Pannelli di legno co
Metodi di prova (Plywod Panels - Gluin
This standard is the official version of
2004 edition). The standatd specifies the
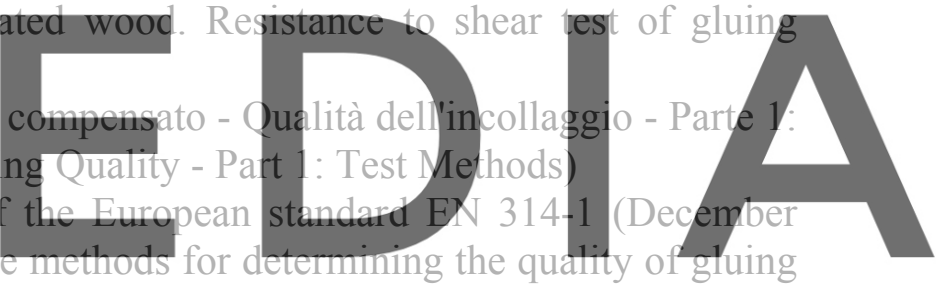

of plywood with veneers, planing boards and lamellar panels by cutting test. The

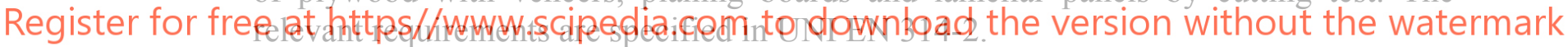

UNI EN 408:2012 - Strutture di legno - Legno strutturale e legno lamellare incollato -

Determinazione di alcune proprietà fissiche e meccaniche. (Structural wood and glued lamellar wood - Determination of certain physical and mechanical properties.)

- UNI EN 384:2016 - Legno strutturale - Determinazione dei valori caratteristici delle proprietà meccaniche e della massa volumica (Structural wood - Determination of characteristic values of mechanical properties and density)

- Linee Guida per la certificazione dell'idoneità tecnica all'impiego di materiali e prodotti innovativi in legno per uso strutturale (DM 14.01.08 - Norme Tecniche per le costruzioni paragrafo 11.1, lettera C) - Guidelines for the certification of technical suitability for the use of innovative wood materials and products for structural use

- UNI EN 16351:2015 Strutture di legno - Pannello di tavole incrociate - Requisiti (Wooden structures - Cross board - Requirements)

- EN 13354:2008 - Solid wood panels (SWP) - Bonding quality - Test method;

This European Standard specifies a test method for determining the bonding quality of single-layer and multi-layer solid wood panels by a shear test. 
From the analysis of the regulations losted above, in order to know the mechanical parameters of the CLT panels, it was considered appropriate to apply the following standards:

- UNI EN 392:1997 - Glued lamellar wood. Trimming resistance test of gluing surfaces.

- UNI EN 408:2012 - Wood structures - Glued structural wood and glulam wood Determination of certain physical and mechanical properties.

It should be noted that the standards chosen for the tests are not specific for CLT panels.

\section{APPLICATIONS}

The overcoming of the problems related to the anisotropy of the raw material, and the possibility of reaching remarkable thicknesses and dimensions, have made these panels an important business reality which is forcefully emerging in various construction sectors.

Willing to investigate the possible applications in the structural restoration field, was noted that these panels have often been used for the refurbishment and reinforcement of existing wooden floors and roofs $[5,6,7,8,9,10,11,12,13]$.

Verifications carried out on masonry buildings located seismic areas often reveal a criticism about the timber ceilings, because in order to guarantee a uniform transfer of the loads to the lateral resistant elements, it should be ensured a diaphragm behavior of floors and inclined rooftops. But instead the real condition is that the wooden horizontal structures had a remarkable deformability, and therefore their behavior is clearly far from a diaphragm one.

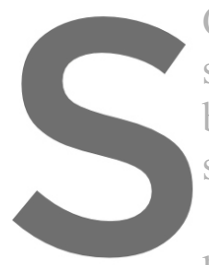
Consequently there is structures. Clearly the by reversible and dry strategies.

With this perspective the CLT panels provide matching the reinforcement needs with those
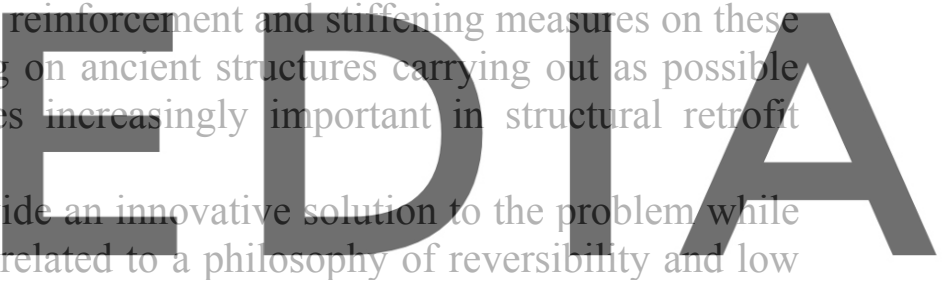
invasiveness of interventions. Numerous scientific studies, experimentations and realizations

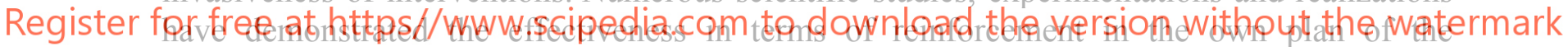

structures. This allow therefore to consider at date these panels as a valid alternative to the traditional techniques of reinforcement.

In the literature, several research groups have shown that for CLT-reinforced horizontal structures, increasing loads apllied, the crisis of the system is reached with the crisis of the connection sections. So it were obtained resistance values 7 times higher than the traditional slabs. The reinforcement of wooden roofs both planar or inclined, represent another possible application of CLT panels in structural restoration. In the literature there are several studies about this topic, in particular in order to evaluate the different possibilities of modelling these kind of structures in relation to the potential dissipative effects that the reinforcements with these panels determine. A plausible modelling hypotesis is to consider the connections between panels and trusses as springs characterized by linear or not linear propreties according on the type of analysis carried out [9]. Regardless of whether the dissipative effects are evaluated, also in this case this reinforcement strategy is effective both in terms of seismic response and in terms of reversibility and low invasiveness.

However, studies conducted on other plausible interventions involving the use of CLT panels are very rare. 
This type of panels could probably be used for the consolidation of the masonry walls by operating a sort of tackle inside the walls themselves [3]. This type of intervention would allow the original appearance of the buildings to be preserved by operating with an almost complete reversibility perspective in full compliance with the buildings both from the aesthetic that from the constituent materials point of view .

\section{EXPERIMENTAL TESTS}

\subsection{Bending Resistance}

In order to investigate the behaviour of the panels, several tests were carried out on samples of panels consisting of 3 and 5 lamellas layers. The 3-layer panels have a height of $100 \mathrm{~mm}$ and consist of external lamellae of a height of $25 \mathrm{~mm}$, while the inner layer is made up of a lamella of a height of $50 \mathrm{~mm}$. The 5-layer panels have a height of $120 \mathrm{~mm}$ with slats of equal thickness of $24 \mathrm{~mm}$. In both types of panels the lamellae are $300 \mathrm{~mm}$ long. The results of the experiments were compared with theoretical calculation models. All tests were carried out according to UNI EN 408:2012. The panels used for the tests are made of wood classified C24 according to UNI EN 338 with the following mechanical characteristics:

\section{$\mathrm{E}_{0}=110000 \mathrm{~N} / \mathrm{mm}^{2} ; \mathrm{E}_{90}=3700 \mathrm{~N} / \mathrm{mm}^{2} ; \mathrm{G}=690 \mathrm{~N} / \mathrm{mm}^{2}$}

The tests were performed by placing the samples on two known centre distance supports

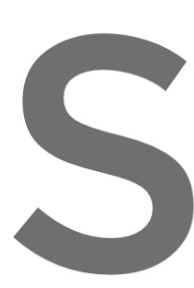
by progressively applying the load in the centr
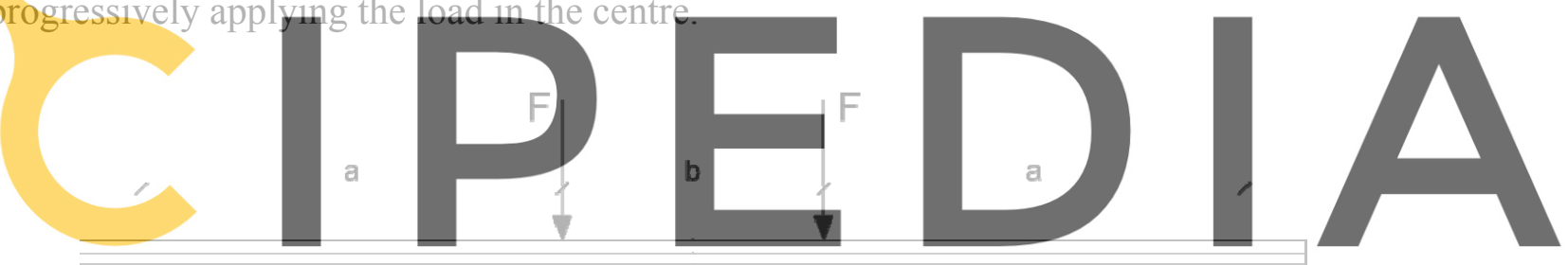

Register for free at/https//www.scipedia.com to dôwnload the version without the watermark † $103 \mathrm{~cm}$

$64 \mathrm{~cm}$

$103 \mathrm{~cm}$

Figure 01: Test load scheme (UNI EN 408:2012)

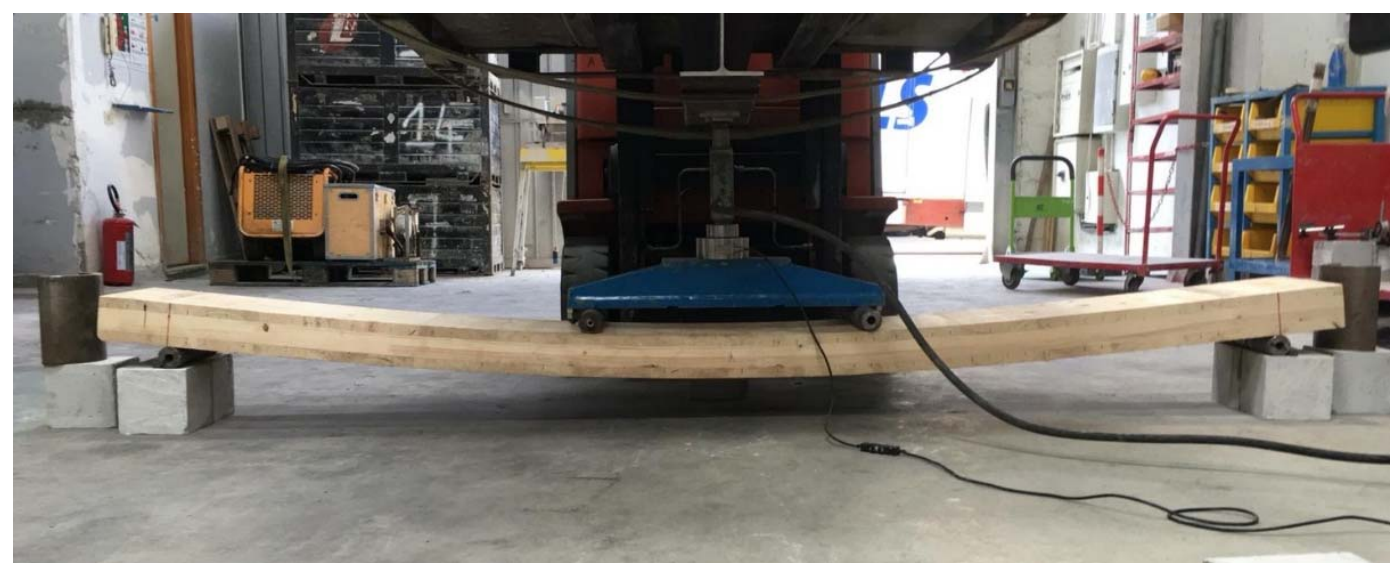

Figure 02: Load test 
Below one of the Force-Displacement diagram is shown:

\begin{tabular}{|c|c||c|c|}
\hline $\begin{array}{c}\text { Load } \\
{[\mathrm{kg}]}\end{array}$ & $\begin{array}{c}\text { Deflection } \\
{[\mathrm{mm}]}\end{array}$ & $\begin{array}{c}\text { Load } \\
{[\mathrm{kg}]}\end{array}$ & $\begin{array}{c}\text { Deflection } \\
{[\mathrm{mm}]}\end{array}$ \\
\hline 0 & 0 & 800 & 50 \\
\hline 100 & 6 & 700 & 42 \\
\hline 200 & 12 & 600 & 39 \\
\hline 300 & 20 & 500 & 32 \\
\hline 400 & 26 & 400 & 26 \\
\hline 500 & 34 & 300 & 18 \\
\hline 600 & 39 & 200 & 11 \\
\hline 700 & 46 & 100 & 6 \\
\hline 800 & 52 & 0 & 1 \\
\hline
\end{tabular}

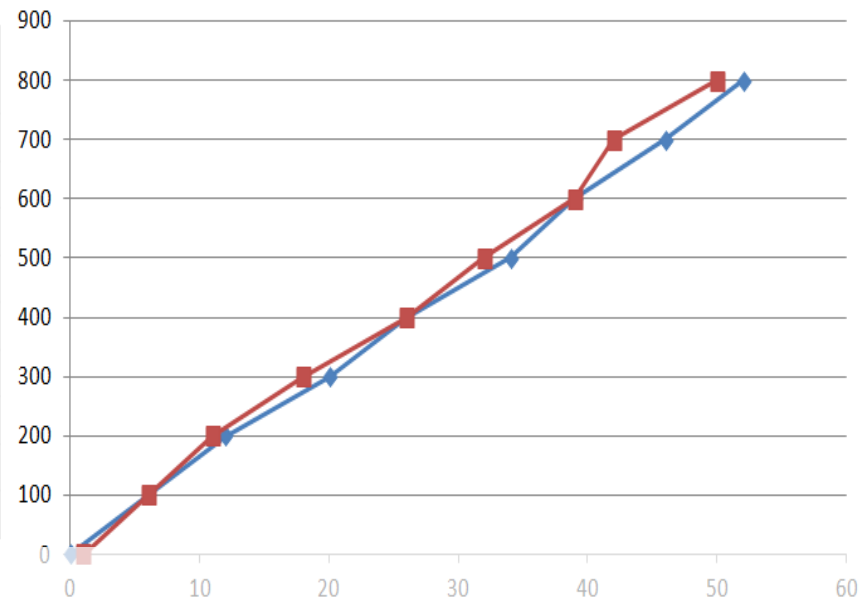

Figure 03: 3-layer panel force-displacement diagram

When the test phase are finished, the theoretical displacement in the centre was calculated using three different models:

Model 1: the calculation of the maximum displacement was performed by neglecting
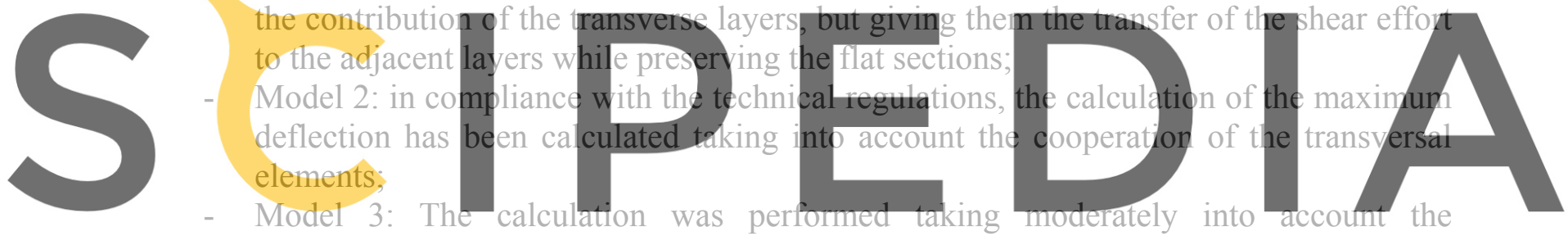

contribution of the transverse layers with their shear deformability.

Register for free at https//www.scipedia.com to download the version without the watermark

The following table summarizes the values obtained from the test (with subscript sp) and from the 3 different calculation models (with subscript $t$ ):

Table 1: Bending test results

\begin{tabular}{cccc|ccc}
\cline { 2 - 4 } \cline { 5 - 7 } & \multicolumn{3}{c}{ 3-LAYER PANEL } & \multicolumn{3}{c}{ 5-LAYER PANEL } \\
\cline { 2 - 4 } \cline { 5 - 7 } & Model 1 & Model 2 & Model 3 & Model 1 & Model 2 & Model 3 \\
\hline $\mathrm{EI}$ & $2,40625 \mathrm{E}+11$ & $2,41781 \mathrm{E}+11$ & $2,37537 \mathrm{E}+11$ & $3,72557 \mathrm{E}+11$ & $3,72685 \mathrm{E}+11$ & $2,37537 \mathrm{E}+11$ \\
\hline $\mathrm{V}_{\mathrm{t}}$ & 24,67 & 24,55 & 24,99 & 13,28 & 13,28 & 13,44 \\
\hline $\mathrm{V}_{\mathrm{sp}}$ & 50,5 & 50,5 & 50,5 & 27 & 27 & 27 \\
\hline
\end{tabular}

The comparison between the experimental values and the theoretical ones show that the displacements values found during the tests are much higher than those obtained from all the theoretical calculation models. This could be due to an incorrect attribution of the EI value to the material in the three calculation models considered. If it was, starting from the experimental data found, it would be necessary to create a model of the CLT material more responsive to reality. The experiments shown in this work have been carried out on a specific standard for lamellar wood which does not necessarily apply well in this case, it should be 
noted.

\subsection{SLIPPING}

In order to investigate the behavior of the gluing surfaces of the CLT panels, and in the absence of specific technical regulations (ref. $\S 2$ ), several tests were carried out on different specimens in according to the provisions contained in the UNI EN 392: 1997 standard "Wood glued lamellar. Shear strength test of gluing surfaces ".

This standard doesn't contain specific provision for the orientation of the fibres in relation to the direction of application of the load. That because the field of application of the regulation, is exclusively laminated wood which as is known, is made with lamellas oriented in the same direction.

In order to considerate the mutual 90 degrees rotation of the lamellas, that is of the fibres, constituting CLT panels, the working group carried out the tests by dividing the samples into two families: the first characterized by the central panel fibres oriented parallel to the direction of load application (SAMPLES TYPE A), the second one with the central panel fibres orthogonal to the direction of application of the load (SAMPLES TYPE B).

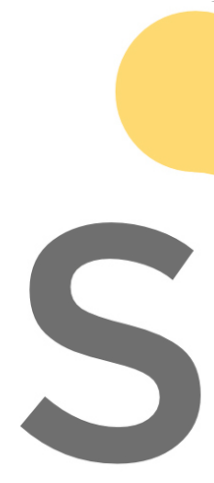

Figure 04: Specimens type

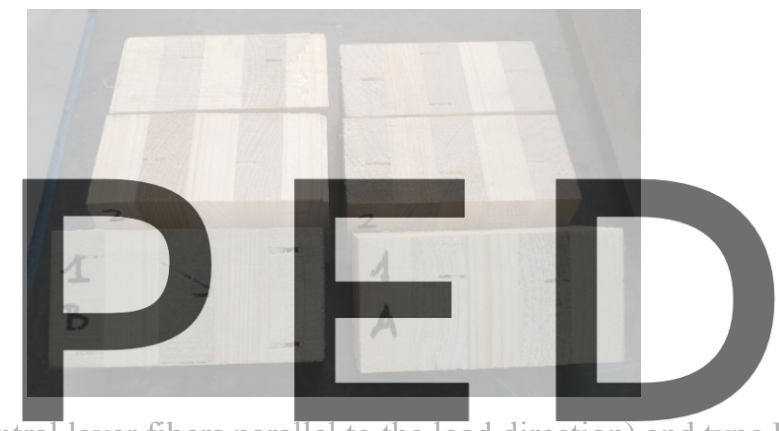

orthogonal to the load direction)

\section{Register for free at https//www.scipedia.com to download the version without the watermark}

The test was carried out on the basis of the scheme described in the standard as shown in the figure below.

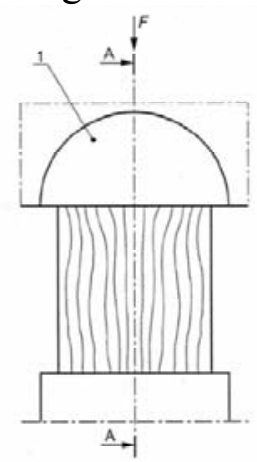

Vista frontale

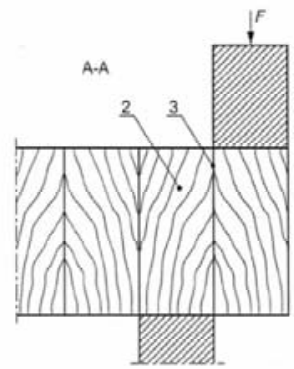

a)

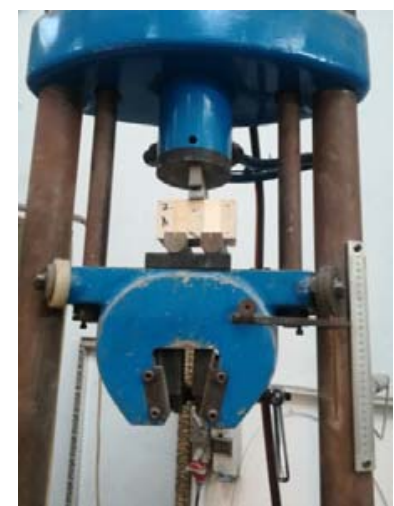

b)

Figure 05: a) Representation of the performed test (UNI EN 392:1997) - b) Laboratory test 
Ten tests were performed, five for each samples family. The results are shown in the table below:

Table 2: Slipping test results

\begin{tabular}{ccccccccc}
\hline Specimen & $\begin{array}{c}\text { Basis } \\
{[\mathrm{mm}]}\end{array}$ & $\begin{array}{c}\text { Width } \\
{[\mathrm{mm}]}\end{array}$ & $\begin{array}{c}\text { Height } \\
{[\mathrm{mm}]}\end{array}$ & $\begin{array}{c}\text { Mass } \\
{[\mathrm{Kg}]}\end{array}$ & $\begin{array}{c}\text { Specific Weight } \\
{\left[\mathrm{Kg} / \mathrm{m}^{3}\right]}\end{array}$ & $\begin{array}{c}\text { Thickness } \\
{[\mathrm{mm}]}\end{array}$ & $\begin{array}{c}\text { Breaking load } \\
{[\mathrm{KN}]}\end{array}$ & $\begin{array}{c}\tau \\
{\left[\mathrm{N} / \mathrm{mm}^{2}\right]}\end{array}$ \\
\hline 1A & 60 & 119 & 60 & 0,178 & 415,500 & 3 & 15,273 & 4,243 \\
\hline 2A & 60 & 119 & 59 & 0,185 & 439,159 & 6 & 20,223 & 5,713 \\
\hline 3A & 60 & 119 & 59 & 0,175 & 415,420 & 5 & 10,888 & 3,076 \\
\hline 4A & 60 & 119 & 60 & 0,176 & 410,831 & 5 & 12,512 & 3,476 \\
\hline 5A & 60 & 119 & 56 & 0,179 & 447,679 & 4 & 14,987 & 4,460 \\
\hline & & & & & & & & \\
\hline 1B & 60 & 119 & 59 & 0,174 & 413,047 & 3 & 7,464 & 2,108 \\
\hline 2B & 60 & 119 & 58 & 0,180 & 434,657 & 6 & 10,928 & 3,140 \\
\hline 3B & 60 & 119 & 60 & 0,185 & 431,839 & 3 & 7,709 & 2,141 \\
\hline 4B & 60 & 119 & 59 & 0,179 & 424,916 & 8 & 15,934 & 4,501 \\
\hline 5B & 60 & 119 & 60 & 0,184 & 429,505 & 9 & 13,769 & 3,825 \\
\hline
\end{tabular}

Analysis of results indicates that samples B resistance values are clearly lower than those of A family. It means that the $\tau$ value for the group A samples are $33 \%$ higher than the B group ones.

By studying the breakage

while for the A samples

crisis occurs with the

The results described
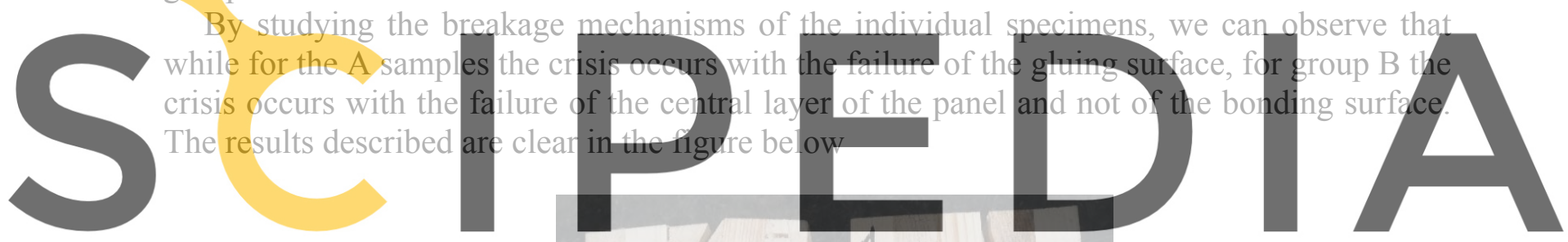

Register for free at https//www.scipèdia.com to download the version without the watermark

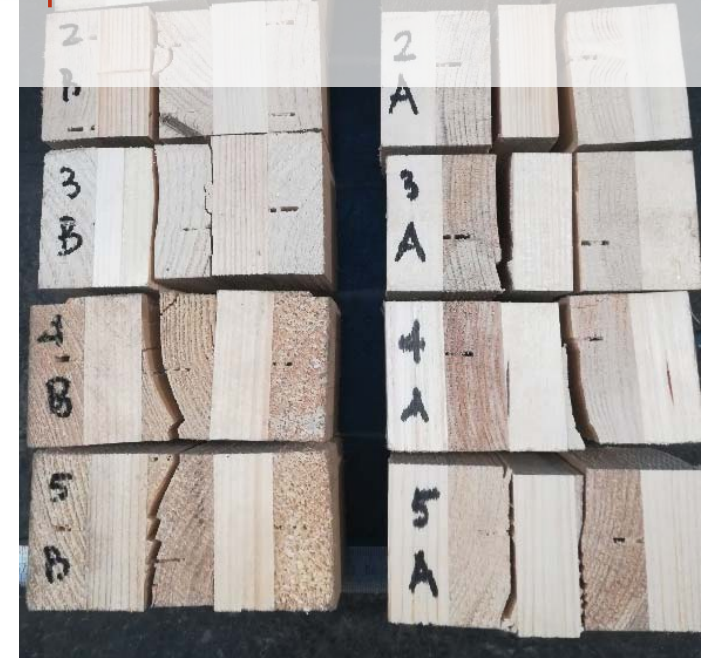

Figure 06: Post test specimens 
All in all, we can affirm that from the tests carried out it is clear that the individual layer orientation assumes considerable importance both in terms of strength, Than in terms of "quality" of breakage, when we want to analyze the parameters that govern breakage by stressing the bonding surfaces.

\section{CONSIDERATIONS AND CONCLUSIONS}

The need to carry out structural restoration interventions that operate according to a philosophy of maximum reversibility and low invasiveness is becoming increasingly important.

In this perspective, the use of wood-based structural products and in particular CLT panels could represent a valid alternative solution to traditional structural restoration methods. In order to meet this requirement, in our opinion, it is necessary to introduce specific technical From the results of the tests shown in this work, it is clear that to date there are still numerous uncertainty factors linked both to the correct choice of the mathematical model to be used to better describe the behavior of the material, than to the presence of a poor regulatory framework related to the tests to be carry out on CLT panels. This work shows therefore that CLT panels cannot be actually tested in the same way as laminated wood.

That is especially in the case with we have to consider the use of CLT panels in the structural restoration for out of their own plan actions

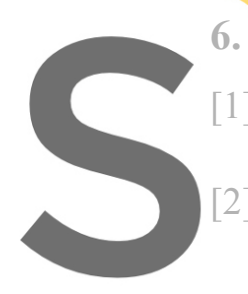

6. REFERENCES

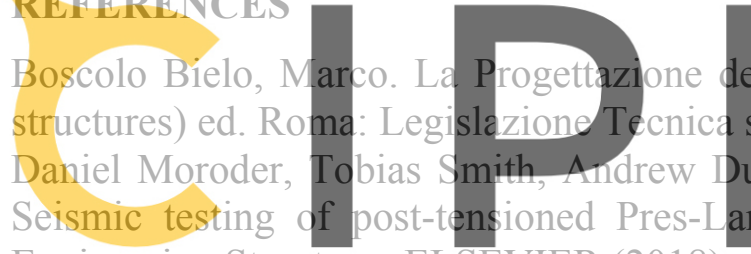

Engineering Structures ELSEVIER (2018)

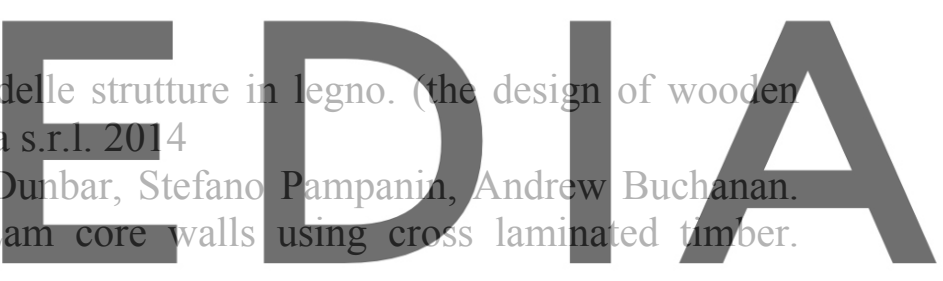

Ivan Giqngo Gianni Schiro Maurizio Piaza. On the use of timber-based pane for the seismic retiofth of masoniry structures. Conference: 3rd Internationa

PROTECTION OF HISTORICAL CONSTRUCTIONS Lisbon (2017)

[4] Sandoli Antonio, Pinto Mirko, Pampanin Stefano, Calderoni Bruno. Protezione sismica di edifici esistenti in c.a. mediante l'utilizzo di pareti lignee post-tese. (Seismic protection of existing buildings in reinforced concrete through the use of post-stretched wooden walls) Pistoia: ANDIS 2017

[5] Roensmaens B., Van Parys L., Carpentier O. and Descamps T. (2018) Refurbishment of existing timber floors with screwed CLT panels, International Journal of Architectural Heritage

[6] Gubana, A. (2015) State-of-the-art report on high reversible timber to timber strengthening interventions on wooden floors. Construction \& Building Materials,

[7] Gubana, A., Melotto, M. Experimental tests on wood-based in-plane strengthening solutions for the seismic retrofit of traditional timber floors. Construction and Building Materials.

[8] Longarini, N., Crespi, P., Scamardo, M. Numerical approaches for cross-laminated timber roof structure optimization in seismic retrofitting of a historical masonry church. 2019 Bulletin of Earthquake Engineering 
[9] Longarini, N., Crespi, P., Zucca, M. Dissipative cross lam roof structure for seismic restoration of historical churches. 2018 REHABEND

[10] Ongaretto, E., Pozza, L., Savoia, M. Wood-based solutions to improve quality and safety against seismic events in conservation of historical buildings. 2016 International Journal for Quality Research

[11] Roensmaens, B., Van Parys, L., Branco, J., Descamps, T. Proposal of a CLT Reinforcement of Old Timber Floors. 2019 RILEM Bookseries

[12] Unuk, Ž., Premrov, M., Žegarac Leskovar, V. Development of an Innovative Approach for the Renovation of Timber Floors with the Application of CLT Panels and Structural Glass Strips. 2019 International Journal of Architectural Heritage

[13] Riggio, M., Tomasi, R., and Piazza M. (2014) Refurbishment of a traditional timber floor with a reversible tech-nique: importance of the investigation campaign for design and control of the intervention. International Journal of Architectural Heritage

[14] Basile Andrea, Frunzio Giorgio, Nicolella Maurizio, Scognamillo Claudio, Analisi LCC per componenti in legno lamellare esposti in esterni. (LCC analysis for laminated wood components exposed to the outside) ISTEA-Re-shaping the construction industryMaggioli Editore (2017)

[15] Frunzio, Giorgio, Di Gennaro, Luciana: Seismic structural upgrade of historical buildings through wooden deckings strengthening: the case of study of Palazzo Ducale in Parete, Italy. Firenze CINPAR 2018 Structural Integrity PROCEDIA ELSEVIER (2018)

[16] Curlante D. - Progettare strutture in legno lamellare, Dario Flaccovio Editore, 2014.

[17] Bellomo V.- Strutture in legno lamellare , Grafill , 2015

[18] Bergamasco, I., Gesualdo, A., Iannuzzo, A. and Monaco, M. (2018) 'An integrated approach to the conservation of the roofing structures in the Pompeian domus', Journal of Cultural Heritage, DOI: 10.1016/j.culher.2017.12.006.

[19] Frunzio, G., D' Agostino, S. (2015) 'Between mechanics and architecture: the quest for the rules of the art', in Masonry Structures: Between Mechanics and Architecture, pp.119, Springer International Publishing

[20] Faggiano, B., Grippa, M.R. and Calderoni, B., 2013. Non-destructive tests and bending tests on chestnut structural timber. In Advanced Materials Research (Vol. 778, pp. 167174). Trans Tech Publications.

[21] Piazza, M.; Modena, R.; Tomasi, R.., 2005 Strutture in legno. Materiale, calcolo e progetto secondo le nuove normative europee. Hoepli Editore.

[22] De Matteis Gianfranco, Corlito Valentina, Guadagnuolo Mariateresa, Tafuro Anna. 2019. Seismic Vulnerability Assessment and Retrofitting Strategies of Italian Masonry Churches of the Alife-Caiazzo Diocese in Caserta. Int. J. Architectural Heritage - Taylor \& Francis

[23] Russo Teresa,Tesi di laurea corso di laurea magistrale in architettura: Costruire con il legno oggi. X-Lam: dal processo produttivo alla sperimentazione in laboratorio. (Master's degree thesis in architecture: Building with wood today. X-Lam: from the production process to laboratory experimentation.) Università degli Studi della Campania LUIGI VANVITELLI 2017/2018 - Relatore Prof. Ing. Frunzio G. 